\title{
Xenocryst geotherms: techniques and application
}

\author{
Herman Grütter \\ ${ }^{I}$ BHP Billiton World Exploration Inc., \#800 Four Bentall, 1055 Dunsmuir Street, \\ Vancouver, B.C., V7X 1L2, Canada
}

\section{Introduction}

Pyroxene-based thermobarometry of mantle xenoliths has benefited from over 40 years' worth of academic research in traditional hard-rock petrology disciplines like experimental petrology, thermodynamic modelling, diffusion kinetics and analytical routines, but ancillary work in the fields of mantle geochemistry and lithosphere-scale geophysics have also impacted interpretation of the origin and geological history of mantle-derived rock fragments brought to Earth's surface by alkaline magmas. Advances in the thermobarometry disciplines over the last $\sim 10-15$ years have enabled users to focus on single-grain techniques, with the advantage that $10^{2}$ to $10^{3}$ full or partial pressure-temperature $(\mathrm{P}-\mathrm{T})$ data may be obtained by routine electron microprobe analysis of mantle-derived xenocrysts in a matter of days, and at relatively low cost. The diamond exploration industry has naturally found substantial commercial application of the new-age single-grain thermobarometry techniques and various stakeholders posses a veritable "treasure trove" of xenocryst P-T-X data related to alkaline magmatic events that occurred through time and across Earth's landmass. Exploration and investment industry regulations in competitive marketoriented jurisdictions like Australia, Brazil, Canada, the USA and in Europe now require disclosure of the xenocryst data and ancillary microdiamond data, thereby offering a glimpse to the academic geoscientific community of mantle variability on a scale much finer than could possibly be accessed with conventional xenolith-based research. By accepting the invitation to speak on the topic of "Xenocryst Geotherms" at 9IKC, I intend to show that (i) P-T data obtained from pyroxene xenocrysts are consistent with those of xenoliths from the same localities, (ii) the compositions of xenocryst orthopyroxenes challenge the "equilibrium" achieved in reversed high-P, moderate- $T$ phase-petrology experiments, (iii) garnetbased P-T techniques are slowly maturing, and (iv) application of single-cpx and single-garnet P-T techniques to readily available public-domain data places constraints on the thickness and thermal evolution of Earth's depleted lithosphere.

\section{Pyroxene geotherms}

Comprehensive reviews of various pyroxene-based thermobarometric formulations applicable to mantle xenoliths are presented elsewhere (e.g. Carswell and Gibb, 1987; Brey and Kohler, 1990; Taylor, 1998) and are not the focus of this talk. Instead I wish to

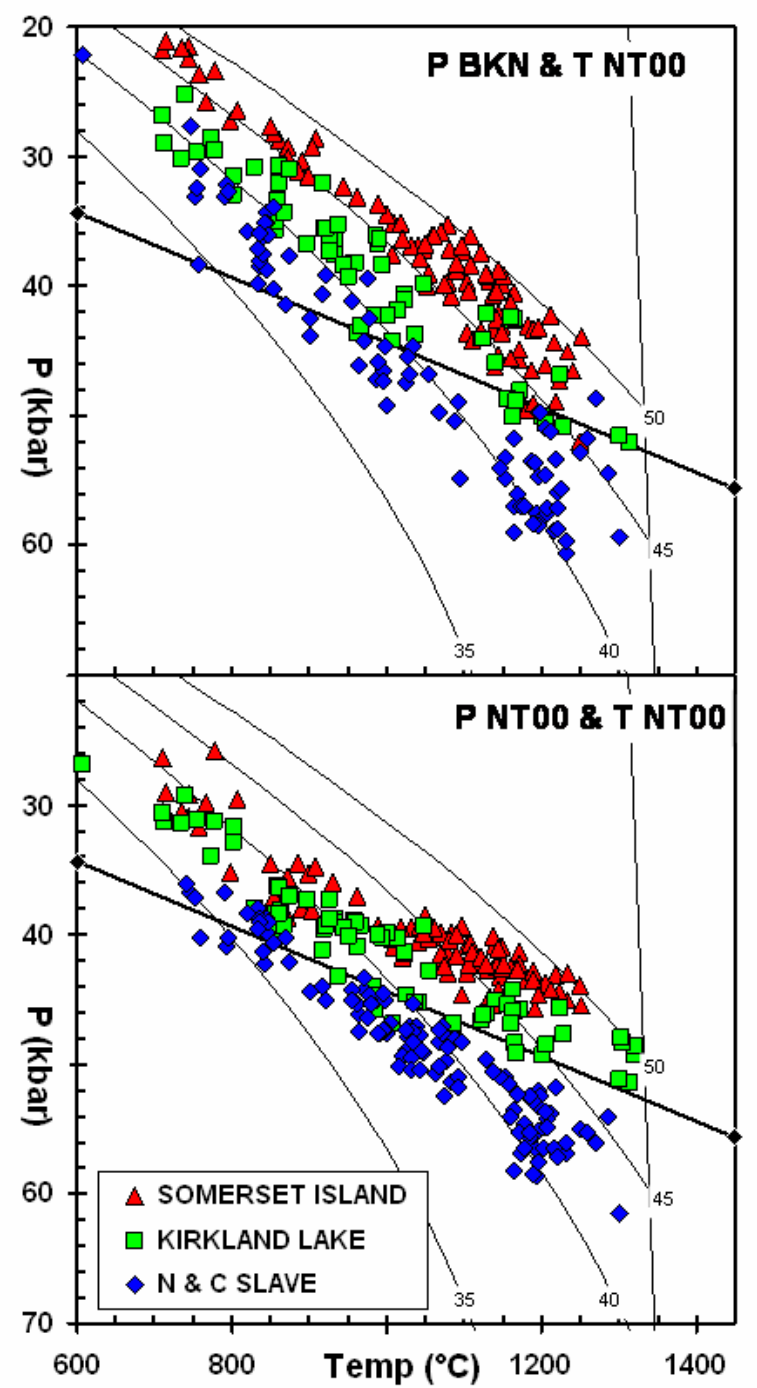

Figs 1 \& 2: Comparison of xenolith-based pyroxene geotherms for Canadian localities (Fig 1, top) with single-cpx geotherms (Fig 2, bottom). Public data.

emphasize that, in stark contrast to most Kaapvaal xenolith localities, the suite of xenolith data now available for Canadian kimberlite localities outlines three distinct pyroxene geotherms, each defined across a complete mantle temperature range from $700^{\circ} \mathrm{C}$ to $1300^{\circ} \mathrm{C}$, and with no data above the $\mathrm{T}_{\mathrm{p}}=1300^{\circ} \mathrm{C}$ mantle adiabat (Fig. 1). Figure 2 shows these features are readily reproduced an a relative sense by the single-cpx thermobarometer of Nimis and Taylor (2000), bolstering confidence in the use of the single-cpx technique to constrain relative geotherms (i.e. PNT00 with TNT00, as in Fig. 2). 
Although opx-based single-grain thermobarometry has long had proponents (e.g. Mercier, 1980), actual applications are restricted by opx grains rarely surviving a peritectic reaction that occurs with respect to most magma compositions. Nevertheless, Fig. 3 shows a simple portrayal of opx compositions from Canadian xenolith localities that clearly outlines the relative disposition of three topical geothermal arrays. Orthopyroxene compositional brackets achieved at a given P\&T in the most recent, carefully reversed, highpressure thermobaromery experiments (Brey et al, 2008) are shown as black rectangles in Fig. 3. Opx in natural xenoliths systematically show far better equilibration within the compositional range of interest, endorsing the use of simple diagrams like Fig. 2 (for single-cpx) or Fig. 3 (for single-opx) to obtain reliable estimates of geothermal conditions.

Rare instances of opx recovery in exploration samples consistently show the same geotherm as constrained by independent means from the source kimberlite(s) (see Fig . 4). The low-Ca opx compositions in Fig. 4 reveal

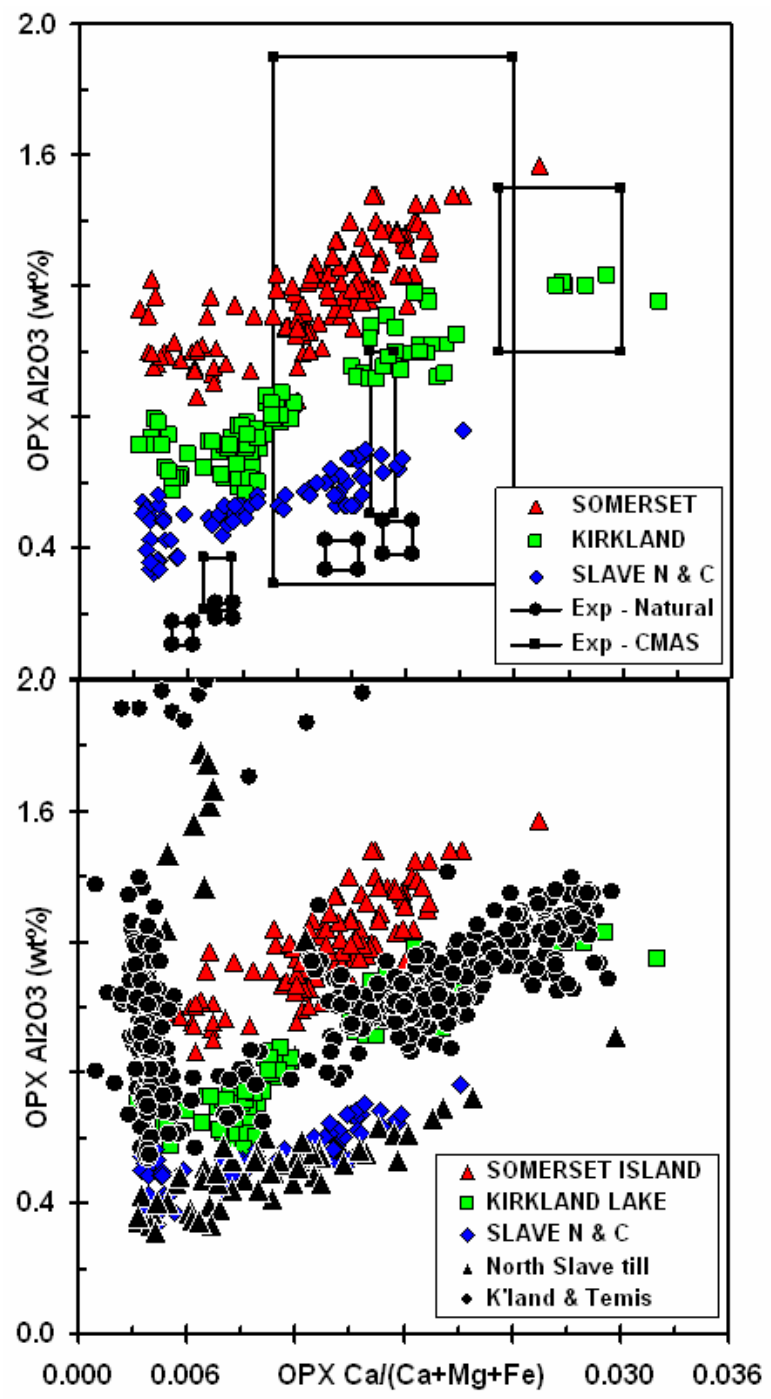

Fig 3 (top): Opx compositions in xenoliths and in experiments. Fig. 4 (bottom): Opx xenocrysts in till samples from the North Slave craton, or Kirkland Lake / Temiskaming region. Public data. the presence of cpx-free garnet harzburgite in the mantle source, while high-Al, low-Ca xenocrysts are derived from spinel peridotite. These interpretations demonstrate the rapid screening, exploration-centred capabilities embedded in diagrams like Figure 3.

\section{Equilibration of pyroxene xenocrysts}

One of the potential criticisms against widespread use of single-pyroxene thermobarometry is the absence of data for coexisting phases, such that a lack of proof of phase-equilibrium is taken to imply that "aberrant" P-T values based on single-pyroxene techniques are unreliable or perhaps inferior to P-T data obtained using classical xenolith-based techniques. I contend that populations of xenocryst data cover the range of mineral compositions from the mantle substantially better than do data for xenoliths, and xenocrysts hence provide better context to interpret results for singlepyroxene and xenolith-based thermobarometry. One example will have to suffice. The clinopyroxene xenocryst compositions shown in Fig. 5 are routinely encountered in kimberlite provinces (e.g. Read et al, 2004), yet only the comprehensive xenolith data set from Colorado-Wyoming kimberlites (Kirkley, 1980) covers a similar compositional range. Based on $\mathrm{Al}+\mathrm{Cr}-$ $\mathrm{Na}-\mathrm{K}$ content (i.e. Al-Tschermacks), the derivation of cpx from spinel-, spinel-garnet or garnet-facies peridotite is readily interpreted for the xenocryst data. That spinel- or spinel-garnet facies pyroxenes always yield underestimated pressures with single-pyroxene or xenolith-based thermobarometry techniques is then readily related to their elevated Al-Tschermacks component, in comparison to garnet-facies grains (Fig. 5). Moreover, the garnet-facies cpx xenocrysts show Al-Tschermacks subtly decreasing with Mg-number, exactly along a known Al-Fe interaction for mutually coexisting opx and cpx. This feature is common to all properly analysed xenocryst cpx data sets and provides reassurance of multi-mineral equilibration in a spinelabsent assemblage comprising opx, cpx and garnet, with olivine being an optional extra. It would be a challenge to interpret the same relationships from the best possible xenolith data set that covers the same compositional space (see Fig. 6).

How thick is depleted lithosphere ?

The recent recognition of $\mathrm{Cr}$-spinel saturated pyrope compositions in garnet xenocryst data from kimberlite has enabled calibration of a graphically intuitive $\mathrm{Cr} / \mathrm{Ca}$ in-pyrope barometer (P38 formulation of Grütter et al, 2006). P38 delivers minimum pressures in generalized applications, but the real pressure at which depleted (Cr-rich) lithosphere exists can readily be constrained where Cr-saturated conditions are in evidence in the common garnet $\mathrm{Cr} 2 \mathrm{O} 3$ vs. $\mathrm{CaO}$ diagram. Garnet xenocryst compositions derived from surficial samples collected within, and down-ice of, the Lac de Gras kimberlite province, central Slave craton, have long been on open file (Armstrong, 2001); a randomly selected subset of the $>65,000$ available records is shown in Figure 7. Variations in data density follow Cr-saturated conditions, indicating stepped sampling 


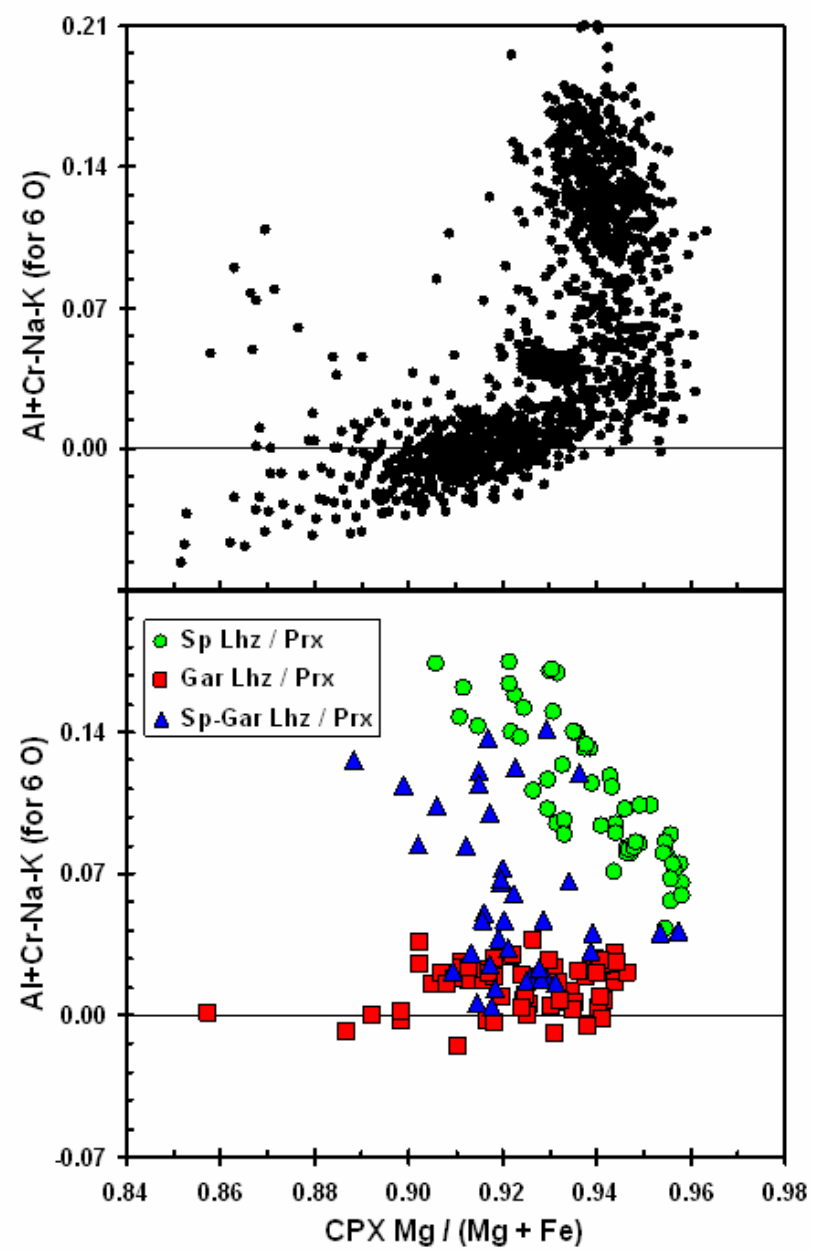

Fig 5 (top): Cpx xenocryst data $(\mathrm{n}=1,316)$ for 13 kimberlites in a single cluster. Fig. 6 (bottom): Cpx compositions $(n=169)$ in spinel-, spinel+garnet- and garnet-facies lherzolite or pyroxenite xenoliths from Colorado-Wyoming. Data from Kirkley (1980).

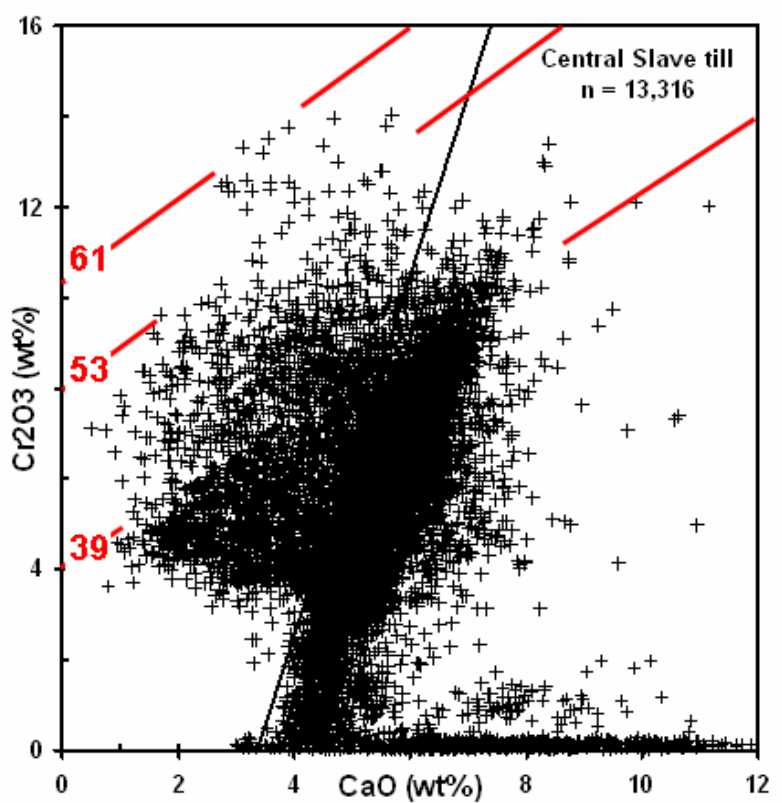

Fig. 7: Cr-pyrope compositions from central Slave craton exploration samples. Cr-saturated arrays occur at 39, 53 and $61 \mathrm{kbar}$ pressure (=depth). Open file data randomly selected from Armstrong (2001). of depleted lithosphere at depths of 39, 53 and $61 \mathrm{kbar}$ $(\sim 120,165$ and $190 \mathrm{~km}$ depth, Fig. 7). Garnet thermometry can be used to restore a samplingunbiased mantle section, and hence to ascertain whether the apparent lithospheric layering has compositional and/or mechanical attributes. Evidence supporting surprisingly thick depleted lithosphere in Proterozoic settings will also be shown at the 9IKC.

\section{Conclusion}

The availability of large public-domain xenocryst data sets and the need to understand Earth's lithosphere at a fine scale will ensure further application and additional improvement of new-age single-grain thermobarometry techniques.

\section{References}

Armstrong, J. P., 2001. Kimberlite Indicator Mineral Chemistry Database (KIMC): A preliminary digital compilation of Kimberlite Indicator Mineral Chemistry extracted from publically available assessment filings; Slave Craton and environs, Northwest Territories and Nunavut, Canada. DIAND NWT Geology Division, DIAND EGS Open Report 2001-02 (CD-ROM).

Brey, G. P., Kohler T., 1990. Geothermobarometry in fourphase lherzolites II: New thermobarometers, and practical assessment of existing thermobarometers. Journal of Petrology 31, 1353-1378.

Brey, G. P., Bulatov, V. K., Girnis, A. V., 2008. Geobarometry for Peridotites: Experiments in Simple and Natural Systems from 6 to $10 \mathrm{GPa}$. Journal of Petrology, 49, 3-24.

Carswell D. A., Gibb, F. G. F., 1987. Evaluation of mineral thermometers and barometers applicable to garnet lherzolite assemblages. Contributions to Mineralogy and Petrology 95, 499-511.

Grütter, H., Latti, D. and Menzies, A., 2006. Cr-saturation arrays in concentrate garnet compositions from kimberlite and their use in mantle barometry. Journal of Petrology, 47, 801-820.

Kirkley, M. B., 1980. Peridotite xenoliths in ColoradoWyoming kimberlites. Unpublished M.Sc. Thesis, Department. of Earth Resources, Colorado State University, Fort Collins, U.S.A., 290 pp.

Mercier, J-C. C., 1980. Single-pyroxene thermobarometry. Tectonophysics. 70, 1-37.

Nimis P. and Taylor W. R., 2000. Single clinopyroxene thermobarometry for garnet peridotites. Part 1. Calibration and testing of a Cr-in-Cpx barometer and an enstatite-in-Cpx thermometer. Contributions to Mineralogy and Petrology 139, 541-554.

Read, G., Grütter, H., Winter, S., Luckman, N., Gaunt, F., Thomsen, F., 2004. Stratigraphic relations, kimberlite emplacement and lithospheric thermal evolution, Quirico basin, Minas Gerais State, Brazil. Lithos 77, 803-818.

Taylor, W.R., 1998. An experimental test of some geothermometer and geobarometer formulations for upper mantle peridotites with application to the thermobarometry of fertile lherzolite and garnet websterite. Neues Jahrbuch Mineralogie Abhandlungen $172,381-408$. 